\title{
AugeTher - Radiocomplexos Dirigidos a Organelos Celulares para Terapia Auger do Cancro
}

$>$

Vasco Bonifácio

vasco.bonifacio@tecnico.ulisboa.pt
- - Os radiofármacos oferecem oportunidades únicas em teranóstica de cancro, pois uma biomolécula dirigida a um alvo molecular específico pode ser marcada com radionuclídeos de diagnóstico ou terapia, permitindo um tratamento adaptado a cada paciente e uma monitorização mais fácil da progressão da doença. Neste domínio, a utilização de radiofármacos emissores de eletrões Auger pode potenciar um tratamento mais eficaz e mais seletivo de tumores e metástases de pequenas dimensões, devido à elevada eficácia biológica de curto alcance deste tipo de partículas. Para tal, é desejável que os radionuclídeos sejam internalizados em organelos radiossensíveis, como o núcleo ou as mitocôndrias. Para atingir este objetivo, o projeto AugerTher propõe complexos macrocíclicos de radiometais trivalentes emissores de eletrões Auger ( ${ }^{11} \mathrm{In} \mathrm{e}^{161 \mathrm{~Tb}} \mathrm{~T}$ ) contendo: i) um inibidor do PSMA (do inglês prostate-specific membrane antigen) para captação seletiva por células do cancro da próstata; ii) farmacóforos com afinidade para o núcleo celular ou as mitocôndrias (por exemplo, derivados de alaranjado de acridina como intercaladores de DNA ou derivados de trifenilfosfónio como grupos mitotrópicos). Alguns dos radiocomplexos serão funcionalizados com espaçadores cliváveis pela catepsina B. A clivagem intracelular do espaçador deverá originar radiocomplexos de menor dimensão, com capacidade melhorada para chegar ao núcleo ou às mitocôndrias. Espera-se que as estratégias desenhadas minimizem a acumulação dos compostos nas mitocôndrias de tecidos saudáveis, reduzindo efeitos secundários indesejados (por exemplo, toxicidade hematológica, lesões renais ou cardiotoxicidade). A execução do plano de investigaç̧ão beneficia do conhecimento e experiência complementares da equipa e dos seus colaboradores internacionais no desenvolvimento e avaliação pré-clínica de potenciais radiofármacos para teranóstica do cancro. A estratégia inovadora proposta poderá ser aplicada a outros emissores de eletrões Auger, abrindo novos caminhos para o desenvolvimento de radiofármacos para a terapia Auger do cancro.
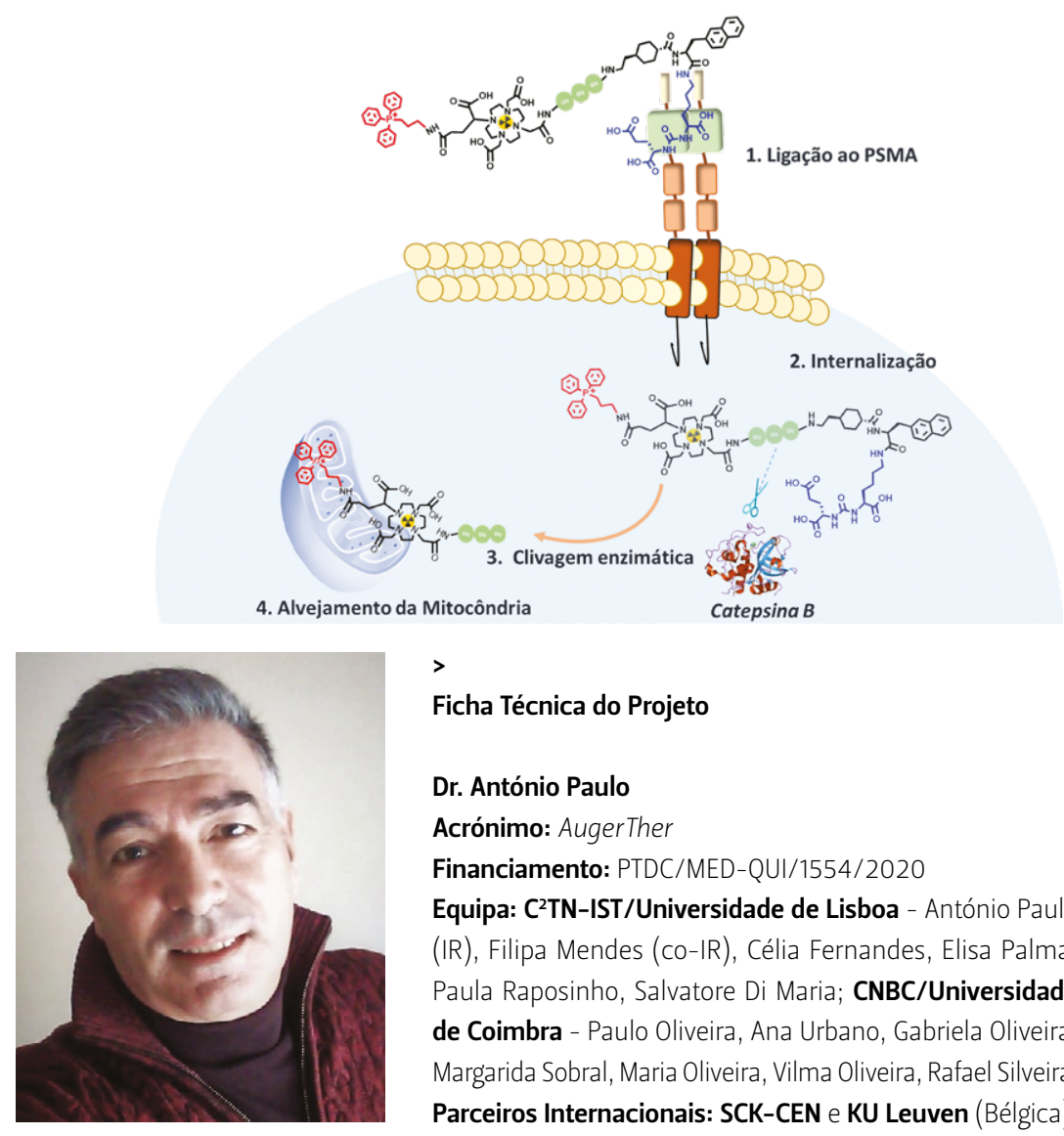

$>$

Ficha Técnica do Projeto

\section{Dr. António Paulo}

Acrónimo: AugerTher

Financiamento: PTDC/MED-QUI/1554/2020

Equipa: C ${ }^{2} \mathrm{TN}$-IST/Universidade de Lisboa - António Paulo (IR), Filipa Mendes (co-IR), Célia Fernandes, Elisa Palma, Paula Raposinho, Salvatore Di Maria; CNBC/Universidade de Coimbra - Paulo Oliveira, Ana Urbano, Gabriela Oliveira, Margarida Sobral, Maria Oliveira, Vilma Oliveira, Rafael Silveira. Parceiros Internacionais: SCK-CEN e KU Leuven (Bélgica). 